\title{
DNA-Binding and Thermodynamic Parameters, Structure and Cytotoxicity of Newly Designed Platinum(II) and Palladium(II) Anti-Tumor Complexes
}

\author{
Hassan Mansouri-Torshizi, "Maryam Saeidifar, Fatemeh Khosravi, Adeleh Divsalar, \\ Ali.Akbar Saboury, ${ }^{\ddagger}$ and Zahra Yekke Ghasemi \\ Department of Chemistry, University of Sistan and Baluchestan, Zahedan, Iran. E-mail: hmtorshizi@hamoon.usb.ac.ir \\ 'Department of Biological Sciences Tarbiat Moallem University, Tehran, Iran \\ Institute of Biochemistry and Biophysics, University of Tehran, Tehran, Iran \\ Received November 27, 2010, Accepted January 14, 2011
}

\begin{abstract}
The complexes $\left[\mathrm{Pd}(\right.$ bpy)(Hex-dtc) $] \mathrm{NO}_{3}$ and $[\mathrm{Pt}($ bpy $)(\mathrm{Hex}-\mathrm{dtc})] \mathrm{NO}_{3}$ (bpy is 2,2'-bipyridine and Hex-dtc is hexyldithiocarbamato ligands) were synthesized and characterized by elemental analysis and spectroscopic studies. The cytotoxicity assay of the complexes has been performed on chronic myelogenous leukemia cell line, K562, at micromolar concentration. Both complexes showed cytotoxic activity far better than that of cisplatin under the same experimental conditions. The binding parameters of the complexes with calf thymus DNA (CT-DNA) was investigated using UV-visible and fluorescence techniques. They show the ability of cooperatively intercalating in CT-DNA. Gel filtration studies demonstrated that platinum complex could cleave the DNA. In the interaction studies between the Pd(II) and Pt(II) complexes with CT-DNA, several binding and thermodynamic parameters have been determined, which may provide deeper insights into the mechanism of action of these types of complexes with nucleic acids.
\end{abstract}

Key Words : DNA binding and thermodynamic parameters, Anti-tumor activity, Pd(II) and Pt(II) complexes

\section{Introduction}

Deoxyribonucleic acid (DNA) is the primary target molecule for most anticancer and antiviral therapies according to cell biology. ${ }^{1,2}$ Therefore, the changing of DNA replication and the inhibiting growth of the tumor cells, which is the basis of designing new and more efficient antitumor drugs and their effectiveness depend on the mode and affinity of the binding. ${ }^{3,4}$ Generally, there are three main kinds of binding models for small molecules with DNA, i.e., (I) intercalation, (II) groove binding, and (III) external electrostatic binding. ${ }^{5-7}$

The main goal of cancer therapy is to attain the maximum therapeutic damage to tumor cells with the minimum concentration of the drug. There have been a number of reports highlighting the use of transition metal complexes as anticancer agents. ${ }^{8-10}$ Current metal-based drugs research is moving towards the development of the new agents able to improve effectiveness and reduce the severe side effects of cis-diamminedichloroplatinum(II) (cisplatin) and its analogues that are still the most widely used anticancer therapeutic. ${ }^{11,12}$ Geometry and complex forming processes of palladium(II) are very similar to those of platinum(II), it was speculated that palladium complexes may also have anti-tumor activities and serve as good models for the understanding of more inert platinum(II) anticancer drugs. ${ }^{11,13-15}$ Therefore, the search continuse for the new potent palladium(II) and platinum(II) complexes possessing high antitumor activity and lack of toxicity and cross-resistance. ${ }^{16}$ It has been reported the $\mathrm{Pd}(\mathrm{II})$ and $\mathrm{Pt}(\mathrm{II})$ complexes with different sulfur containing ligands such as cysteine, cysta- mine, penicilamine, methionine, thiourea, thiosulphate and dithiocarbamate derivatives could overcome some toxicity of cisplatin or its analougos..$^{17,18}$

The present work is an extension of previously studied platinum(II) and palladium(II) complexes of 2,2'-bipyridine and dithiocarbamate derivatives with potentially interesting biological activities. ${ }^{17-19}$ It describes the synthesis and spectroscopic properties of two newly designed antitumor active palladium(II) and platinum(II) complexes with dithiocarbamate. In this work, we described the DNA binding and thermodynamic parameters as well as evaluation of binding modes of the complexes. The antitumor activity in vitro of complexes was investigated against leukemia cell line K562 and compared with the activity of cisplatin.

\section{Experimental Section}

Materials and Methods. Palladium(II) chloride anhydrous, sodium chloride, $\mathrm{NaOH}$ and $\mathrm{KBr}$ were obtained from Fluka (Switzerland). Hexylamine, $\mathrm{AgNO}_{3}$ and carbon disulfide were purchased from Aldrich (England). Potassium tetrachloroplatinate, 2,2'-bipyridine, Sephadex G-25 and Tris-HCl buffer were obtained from Merck (Germany). Highly polymerized calf thymus DNA sodium salt and ethidium bromide (EB) were obtained from Sigma Chemical Co. (USA) and used as received. Other chemicals used were of analytical reagent or higher purity grade. Solvents used were of reagent grade and purified before use by the standard methods and the doubly distilled water was used all along. $\left[\mathrm{Pt}(\mathrm{bpy}) \mathrm{Cl}_{2}\right]$ and $\left[\mathrm{Pd}(\mathrm{bpy}) \mathrm{Cl}_{2}\right]$ were prepared by the procedures described in the literature. ${ }^{20}$ All the experiments 
involving interaction of the complexes with CT-DNA were performed in Tris- $\mathrm{HCl}$ buffer $(20 \mathrm{mM})$ of $\mathrm{pH} 7.0$ medium containing $20 \mathrm{mM} \mathrm{NaCl}$. Sodium salt was used to adjust the ionic strength of the solution. ${ }^{21}$ A solution of CT-DNA gave a ratio of UV absorbance at 260 and $280 \mathrm{~nm}$ more than 1.8, indicating that CT-DNA was sufficiently free from protein. ${ }^{22}$ The concentration of CT-DNA was determined spectrophotometrically using a molar absorptivity of $6600 \mathrm{M}^{-1} \mathrm{~cm}^{-1}$ $(260 \mathrm{~nm}){ }^{23}$ The stock solution of $\mathrm{Pd}(\mathrm{II})$ and $\mathrm{Pt}(\mathrm{II})$ complexes $(0.1 \mathrm{mM}$ and $0.5 \mathrm{mM}$, respectively) were made in the above-mentioned Tris- $\mathrm{HCl}$ buffer by gentle stirring and heating at $308 \mathrm{~K}$, while that of CT-DNA $(4 \mathrm{mg} / \mathrm{mL})$ at $241 \mathrm{~K}$ until homogenous and used for about a week only.

${ }^{1} \mathrm{H}$ NMR spectra were recorded on a Brucker DRX-500 Avance spectrometer at $500 \mathrm{MHz}$ in DMSO- $d_{6}$ using tetramethylsilane as internal reference. Infrared spectra of the metal complexes were recorded on a $J_{\mathrm{AS} . \mathrm{CO}^{-}} 460$ Plus FT-IR spectrophotometer in the range of 4000 to $400 \mathrm{~cm}^{-1}$ in $\mathrm{KBr}$ pellets. Microchemical analysis of carbon, hydrogen, and nitrogen for the complexes was carried out on Herause CHNO-RAPID elemental analyzer. Electronic absorption spectra of the title metal complexes were measured on a $J_{\text {As.co }}$ UV/vis-7850 recording spectrophotometer. Fluorescence intensity measurements were carried out on a Hitachi spectrofluorimeter model MPF-4. Conductivity measurements of the above platinum and palladium complexes were carried out on a Systronics conductivity bridge 305 , using a conductivity cell of cell constant 1.0. Melting points were measured on a Unimelt capillary melting point apparatus and were reported uncorrectedly. The following spectrometric measurements were all performed in a quartz cuvette of $1 \mathrm{~cm}$ path length.

\section{Preparation of Ligand and Metal Complexes.}

Preparation of Hexyldithiocarbamate Sodium Salt (Hex-dtcNa): The preparation of this ligand was carried out using our previous procedure, ${ }^{18}$ except that butylamine was replaced by hexylamine $(13.2 \mathrm{~mL}, 100 \mathrm{mmol})$. The yield was $7.5 \mathrm{~g}(78 \%)$ with melting point of $138^{\circ} \mathrm{C}$. Anal. Calcd. For $\mathrm{C}_{7} \mathrm{H}_{14} \mathrm{NS}_{2} \mathrm{Na}$ (199): C, 42.19; H, 7.03; N, 7.03\%. Found: C, 42.13; H, 7.00; N, 7.04\%. Solid-state FT-IR spectroscopy of the above ligand shows three main characteristic bands at 1491, 983 and $3185 \mathrm{~cm}^{-1}$ assigned to $v$ (N-CSS), $v$ (SCS) and $v(\mathrm{~N}-\mathrm{H})$ modes respectively. ${ }^{18}{ }^{1} \mathrm{H}$ NMR $(500 \mathrm{MHz}$, DMSO- $d_{6}, \mathrm{ppm}, \mathrm{m}=$ multiplet and $\mathrm{sb}=$ singlet broad): 0.84 (m, 3H, H-a), 1.24 (m, 6H, H-b), 1.41 (m, 2H, H-c), 3.32 (m, $2 \mathrm{H}, \mathrm{H}-\mathrm{d})$ and 7.98 (sb, -NH-) (Scheme 1).

Preparation of $[\mathrm{Pd}(\mathrm{bpy})(\mathrm{Hex}-\mathrm{dtc})] \mathrm{NO}_{3}$ : This complex was synthesized following our previous procedure, ${ }^{18}$ except that Bu-dtcNa was replaced by Hex-dtcNa. Yield (67\%) and decomposes at $180^{\circ} \mathrm{C}$. Analysis calculated for $\mathrm{C}_{17} \mathrm{H}_{22} \mathrm{~N}_{4} \mathrm{O}_{3} \mathrm{~S}_{2} \mathrm{Pd}$ (500): C, 40.80; H, 4.40; N, $11.20 \%$. Found: C, 40.65; H, 4.39; N, 11.00\%. Solid-state FT-IR spectroscopy of the complex shows three main characteristic stretching bands at 1551,1026 and $2985 \mathrm{~cm}^{-1}$ assigned to $v$ (N-SS), $v$ (SCS) and $v(\mathrm{~N}-\mathrm{H})$ modes respectively. ${ }^{15,24}$ The sharp band at $1384 \mathrm{~cm}^{-1}$ is assigned to uncoordinated $\mathrm{NO}_{3}^{-}$ ion. ${ }^{25} \mathrm{H}$ NMR $\left(500 \mathrm{MHz}\right.$, DMSO- $d_{6}, \mathrm{ppm}, \mathrm{sb}=$ singlet

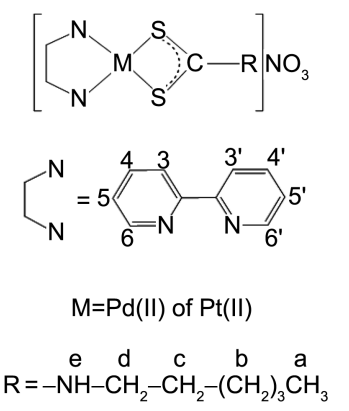

Scheme 1. Proposed structures and proton nmr numbering schemes of $[\mathrm{Pd}(\mathrm{bpy})(\mathrm{Hex}-\mathrm{dtc})] \mathrm{NO}_{3}$ and $[\mathrm{Pt}(\mathrm{bpy})(\mathrm{Hex}-\mathrm{dtc})] \mathrm{NO}_{3}$.

broad, $\mathrm{d}=$ doublet, $\mathrm{t}=$ triplet and $\mathrm{m}=$ multiplet $):{ }^{26} 0.83(\mathrm{~m}$, $3 \mathrm{H}, \mathrm{H}-\mathrm{a}), 1.23$ (m, 6H, H-b), 1.54 (m, 2H, H-c), 3.40 (m, 2H, H-d), 11.21 (sb, 1H, H-e), 7.71 (t, 2H, H-4,4'), 8.22 (t, 2H, H-5,5'), 8.32 (d, 2H, H-3,3'), 8.54 (d, 2H, H-6,6') (Scheme 1). Molar conductance of the complex is $92 \Omega^{-1} \mathrm{~mol}^{-1} \mathrm{~cm}^{2}$ indicating 1:1 electrolytes. ${ }^{27}$ Electronic spectra exhibit four bands. The bands at $319(\varepsilon=2.13)$ and $308(\varepsilon=2.06)$ are assigned to MLCT and the other bands at $249(\varepsilon=5.71)$ and $201(\varepsilon=3.57)$ may be assigned to first and second intraligand $\pi-\pi^{*}$ transition of 2,2'-bipyridine ligand as well as $-\mathrm{CSS}^{-}$group of dithiocarbamate ligand. ${ }^{14}$

Preparation of $\left[\operatorname{Pt}(\right.$ bpy)(Hex-dtc) $] \mathrm{NO}_{3}$ : This complex was prepared by a similar method to that of $[\operatorname{Pd}(\mathrm{bpy})$ (Hex-dtc) $] \mathrm{NO}_{3}$, except $\left[\mathrm{Pt}(\mathrm{bpy}) \mathrm{Cl}_{2}\right]$ was used in place of $\left[\mathrm{Pd}(\mathrm{bpy}) \mathrm{Cl}_{2}\right]$. The yield was $77 \%$ and the product decomposes at $193{ }^{\circ} \mathrm{C}$. Analysis calculated for $\mathrm{C}_{17} \mathrm{H}_{22} \mathrm{~N}_{4} \mathrm{O}_{3} \mathrm{~S}_{2} \mathrm{Pt}$ (589): $\mathrm{C}, 34.63 ; \mathrm{H}, 3.74 ; \mathrm{N}, 9.51 \%$. found: $\mathrm{C}, 34.61 ; \mathrm{H}, 3.75$; $\mathrm{N}, 9.50 \%$. solid state FT-IR spectroscopy of the above complex shows three characteristic stretching bands at 1575, 1030 and $2950 \mathrm{~cm}^{-1}$ assigned to $v$ (N-CSS), $v$ (SCS) and $v$ (N-H) modes respectively. ${ }^{15,24}$ The sharp band at $1385 \mathrm{~cm}^{-1}$ is assigned to uncoordinated $\mathrm{NO}_{3}^{-}$ion. ${ }^{25}{ }^{1} \mathrm{H}$ NMR (500 MHz, DMSO- $d_{6}, \mathrm{ppm}, \mathrm{Sb}=$ singlet broad, $\mathrm{t}=$ triplet, $\mathrm{d}=$ doublet and $\mathrm{m}=$ multiplet: ${ }^{26} 0.87(\mathrm{t}, 3 \mathrm{H}, \mathrm{H}-\mathrm{a}), 1.31(\mathrm{~m}, 6 \mathrm{H}$, H-b), 1.64 (t, 2H, H-c), 3.53 (t, 2H, H-d), 11.59 (sb, 1H, He), 7.78 (t, 2H, H-4,4'), $8.47\left(\mathrm{t}, 2 \mathrm{H}, \mathrm{H}-5,5^{\prime}\right), 8.6$ (d, 2H, H$\left.3,3^{\prime}\right), 8.73\left(\mathrm{~d}, 2 \mathrm{H}, \mathrm{H}-6,6^{\prime}\right)$ (Scheme 1). Molar conductance of the complex is $99.44 \Omega^{-1} \mathrm{~mol}^{-1} \mathrm{~cm}^{2}$ indicating 1:1 electrolytes. ${ }^{27}$ Electronic spectra exhibit five bands. The band at $366(\varepsilon=3.78)$ is assigned to MLCT and the other bands may be due to first, second, and higher internal $\pi-\pi^{*}$ transitions of 2,2'-bipyridine and dithiocarbate ligands. ${ }^{14}$

Cytotoxic Studies. Cell proliferation was evaluated by using a system based on the tetrazolium compound [3-(4,5dimethylthiazol-2-yl)-2,5-diphenyltetrazolium bromide, MTT] which is reduced by living cells to yield a soluble formazan product that can be assayed colorimetrically..$^{28-30}$ The MTT assay is dependent on the cleavage and conversion of the soluble yellowish MTT to the insoluble purple formazan by active mitochondrial dehydrogenase of living cells. The human cancer cell line K562 was grown in an incubator at $310 \mathrm{~K}$ in a humidified atmosphere consisting of $5 \% \mathrm{CO}_{2}$ and $95 \%$ air, being maintained in a PRMI medium supplemented with $10 \%$ heat-inactivated fetal calf serum 
and $2 \mathrm{mM} \mathrm{L}$-glutamine, streptomycin and penicillin $(5 \mu \mathrm{g} /$ $\mathrm{mL}$ ). The harvested chronic myelogenous leukemia cells were seeded at a density $2.0 \times 10^{4}$ cells $/ \mathrm{ml}$ into 96 -well plate with varying concentrations of the sterilized drugs (0-250 $\mu \mathrm{M})$ and incubated for 24 hours. At the end of four hours incubations $25 \mu \mathrm{L}$ of MTT solution ( $5 \mathrm{mg} / \mathrm{mL}$ in PBS) was added to each well containing, fresh and cultured medium. ${ }^{31}$ The insoluble formazan produced was then dissolved in solution containing 10\% SDS and 50\% DMF (under dark condition for $2 \mathrm{~h}$ at $310 \mathrm{~K}$ ), and optical density (OD) was read against reagent blank with multi well scanning spectrophotometer (ELISA reader, Model Expert 96, Asys Hitchech, Austria) at a wavelength of $570 \mathrm{~nm}$. Absorbance is a function of concentration of converted dye. The OD value of study groups was divided by the OD value of untreated control and presented as percentage of control (as 100\%). Results were analyzed for statistical significance using twotailed Student's t-test. Changes were considered significant at $p<0.05$.

DNA Binding Experiments. The stock solutions of Pd(II) and $\mathrm{Pt}(\mathrm{II})$ complexes as well as CT-DNA were made in the above mentioned Tris- $\mathrm{HCl}$ buffer of $\mathrm{pH} 7.0$ medium containing $20 \mathrm{mM}$ sodium chloride. All the experiments involving interaction studies also were carried out in the same buffer. ${ }^{32,33}$ The metal complex solutions, with and without CT-DNA were incubated at $300 \mathrm{~K}$ and $310 \mathrm{~K}$. Then, the spectrophotometric readings at $\lambda_{\max }(\mathrm{nm})$ of the complexes where DNA has no absorption were measured. Using trial and error, the incubation time for solutions of DNA-metal complexes at $300 \mathrm{~K}$ and $310 \mathrm{~K}$ was found to be $6 \mathrm{~h}$. No further changes were observed in the absorbance reading after longer incubation.

Electronic Absorption Studies. It is well known that electronic absorption spectroscopy is an effective method for the binding studies of metal complexes with CT-DNA. ${ }^{34-36}$ In this experiment, the sample cell was filled with $1.8 \mathrm{~mL}$ DNA of $0.165 \mathrm{mM}$ for Pd(II) system and $0.213 \mathrm{mM}$ for $\mathrm{Pt}(\mathrm{II})$ system. In these concentrations, the absorption of DNA is around 1.09 and 1.41 , respectively. However, reference cell is only filled with $1.8 \mathrm{~mL}$ Tris- $\mathrm{HCl}$ buffer. Both cells were set separately at constant temperature of $300 \mathrm{~K}$ or $310 \mathrm{~K}$, and then $20 \mu \mathrm{L}$ from $\mathrm{Pd}(\mathrm{II})(0.1 \mathrm{mM})$ or $50 \mu \mathrm{L}$ from $\mathrm{Pt}(\mathrm{II})(0.5 \mathrm{mM})$ was added to each cell. After $3 \mathrm{~min}$, the absorption was recorded at $260 \mathrm{~nm}$ for DNA and at $640 \mathrm{~nm}$ to eliminate the interference of turbidity. Addition of metal complex to both cells was continued until no further changes in the absorption readings were observed.

Absorption spectral titration experiment was performed by keeping the concentration of the drugs constant $(75 \mu \mathrm{L}$ and $100 \mu \mathrm{L}$ from $0.1 \mathrm{mM}$ stock of $\mathrm{Pd}(\mathrm{II})$ complex and $90 \mu \mathrm{L}$ and $95 \mu \mathrm{L}$ from $0.5 \mathrm{mM}$ stock of $\mathrm{Pt}(\mathrm{II})$ complex at $300 \mathrm{~K}$ and $310 \mathrm{~K}$, respectively) while varying the CT-DNA concentrations $(30-130 \mu \mathrm{L}$ and $30-120 \mu \mathrm{L}$ from $1.15 \mathrm{mM}$ stock solution of DNA for Pd(II) complex and 28-62 $\mu \mathrm{L}$ and 25$39 \mu \mathrm{L}$ from $0.8 \mathrm{mM}$ stock solution of DNA for Pt(II) complex AT $300 \mathrm{~K}$ and $310 \mathrm{~K}$, respectively) in total volume of $2 \mathrm{~mL}$.
In the interaction of the metal complexes with CT DNA, the procedures followed to determine thermodynamic parameters: molar Gibbs free energy of binding $\Delta G_{\left(\mathrm{H}_{2} \mathrm{O}\right)}^{\mathrm{o}}$, molar enthalpy of binding $\Delta H_{\left(\mathrm{H}_{2} \mathrm{O}\right)}^{\mathrm{O}}$, and molar entropy of binding $\Delta G_{\left(\mathrm{H}_{2} \mathrm{O}\right)}^{\mathrm{o}}$ were similar to what was reported earlier. ${ }^{37} \mathrm{~m}$, measure of the metal complex ability to destabilize CT-DNA were found out using Pace method. ${ }^{10,38}$ Also, the other binding parameters: $n, K$, and $g$, where $n$ is Hill coefficient, $g$ is the number of binding sites per 1000 nucleotides of DNA, and $K$ is apparent binding constant, were determined according to reported method. ${ }^{39}$ All measurements were performed separately at $300 \mathrm{~K}$ and $310 \mathrm{~K}$ and repeating three times for these complexes.

For the gel filtration experiments, CT-DNA $(68.4 \mu \mathrm{M}$ and $26.65 \mu \mathrm{M}$ for pd(II) and Pt(II) complexes, respectively) was interacted with $\mathrm{pd}(\mathrm{II})$ and $\mathrm{Pt}(\mathrm{II})$ complexes $(10 \mu \mathrm{M}$ and $48.49 \mu \mathrm{M}$, respectively) for $6 \mathrm{~h}$ at $300 \mathrm{~K}$ in Tris-HCl buffer. Each DNA-metal complex solution was then passed through a Sephadex G-25 column equilibrated with the same buffer. The elusion of the column fractions of $2.0 \mathrm{~mL}$ was monitored at $315 \mathrm{~nm}$ for $\mathrm{Pd}(\mathrm{II})$ complex and $321 \mathrm{~nm}$ for $\mathrm{Pt}(\mathrm{II})$ complex and $260 \mathrm{~nm}$ for both systems.

Flurescence Measurments. For florescence experiment, CT-DNA was pretreated with EB for $30 \mathrm{~min}$. To this pretreated CT-DNA solution various amount of $\mathrm{Pd}(\mathrm{II})$ or $\mathrm{Pt}(\mathrm{II})$ complex were added and their effection on the emission intensity was measured at $300 \mathrm{~K}$ temperature. Moreover, fluorescence intensity of each metal complex at the highest denaturant concentration at $471 \mathrm{~nm}$ excitation wavelength has been checked, and the emission intensities of the two compounds in the range of $540-700 \mathrm{~nm}$ was very small and negligible.

\section{Results and Discussion}

The compounds correspond to the composition HexdtcNa, $[\mathrm{Pd}(\mathrm{bpy})(\mathrm{Hex}-\mathrm{dtc})] \mathrm{NO}_{3}$ and $[\mathrm{Pt}(\mathrm{bpy})(\mathrm{Hex}-\mathrm{dtc})] \mathrm{NO}_{3}$, where bpy=2,2'-bipyridine and Hex-dtc=hexyldithiocarbamato ligands were prepared and characterizad by: chemical analysis, conductance measurements, ultraviolet-visible, infrared and ${ }^{1} \mathrm{H}-\mathrm{NMR}$ spectroscopic methods. These analytical data of the complexes are given in experimental section and the proposed structure in Scheme 1. Cytotoxicity and detailed calf thymus DNA-binding studies of these watersoluble complexes have been studied:

Cytotoxic Activity. The prepared complexes were tested for their in vitro cytotoxic activity by MTT assay. $\mathrm{IC}_{50}$ values were estimated for chronic myelogenous leukemia cell line, K562. Figure 1 reveals the effect on cell growth after a treatment period of 24 hours. The Ic $\mathrm{c}_{50}$ value of the $\mathrm{Pd}(\mathrm{II})$ complex is $80 \mu \mathrm{M}$ and the $\mathrm{Pt}(\mathrm{II})$ complex is $20 \mu \mathrm{M}$. Among the compounds studied here, both complexes exhibit cytotoxic activity and $\mathrm{Pt}(\mathrm{II})$ complex demonstrates more active than $\mathrm{Pd}(\mathrm{II})$ complex. Thus, both may be potential antitumor agent. Furthermore, $\mathrm{Ic}_{50}$ value of cisplatin under the same experimental conditions was determined. This value $(154 \mu \mathrm{M})$ is much higher as compared to the $\mathrm{Ic}_{50}$ values of 


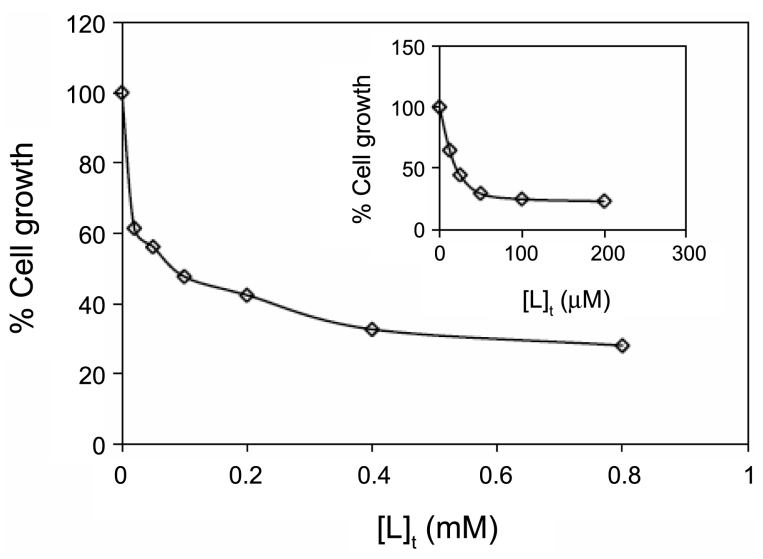

Figure 1. The growth suppression activity of the $\mathrm{Pd}(\mathrm{II})$ complex and the inset for $\mathrm{Pt}(\mathrm{II})$ complex on K562 cell line was assessed using MTT assay as described in material and methods. The tumor cells were incubated with varying concentrations of the complexes for $24 \mathrm{~h}$.

the above two complexes. However, the $\mathrm{Ic}_{50}$ values of these complexes are comparable with those of our analogous $\mathrm{Pd}(\mathrm{II})$ and $\mathrm{Pt}(\mathrm{II})$ dithiocarbamate complexes reported earlier. ${ }^{14,18,19,24}$

Denaturation of CT-DNA by the Pt(II) and Pd(II) Complexes. The profiles of denaturation of DNA by $[\mathrm{Pd}($ bpy $)(\mathrm{Hex}-\mathrm{dtc})] \mathrm{NO}_{3}$ are shown in Figure 2, the inset is denaturation of CT-DNA by $[\mathrm{Pt}(\mathrm{bpy})(\mathrm{Hex}-\mathrm{dtc})] \mathrm{NO}_{3}$ at the two temperatures of $300 \mathrm{~K}$ and $310 \mathrm{~K}$. The concentration of metal complexes in the midpoint of transition, $[\mathrm{L}]_{1 / 2}$, for $\mathrm{Pd}(\mathrm{II})$ complex at $300 \mathrm{~K}$ is $0.025 \mathrm{mM}$ and at $310 \mathrm{~K}$ is 0.024 $\mathrm{mM}$ and for Pt(II) complex at $300 \mathrm{~K}$ is $0.199 \mathrm{mM}$ and at 310 $\mathrm{K}$ is $0.163 \mathrm{mM}$. The improving effect of the temperature, leading to the decrease in $[\mathrm{L}]_{1 / 2}$ from 0.199 to 0.163 for $\mathrm{Pt}(\mathrm{II})$ system, indicates that the increase in the temperature lowers the stability of the DNA against denaturation caused by this complex. The important observation of this work is the low values of $[\mathrm{L}]_{1 / 2}$ for these complexes, ${ }^{21,40}$ that is, both complexes (especially Pd(II) complex) can denature DNA at very low concentrations. Thus, if these complexes are used as anti-tumor agents, low doses will be needed, this may have fewer side effects. It is noticeable that, absorbance of DNA at $260 \mathrm{~nm}$ should increase in presence of increasing amount of each metal complex (denaturant agent). The decrease in the absorbance at $260 \mathrm{~nm}$ with increase of amount of metal complexes added to CT-DNA may be due to: (i) a possibility that interaction between CT-DNA and the metal complexes cause the double helix of CT-DNA to become more straight leading to stacking. This stacking may cause conformational changes leading to a sort of denaturation, or (ii) each strand after denaturation get associated in a more stacked structure and (iii) metal complexes slip into the helix and mask the hydrophobic bases leading to a decrease in absorbance.

In the interaction of the metal complexes with CT-DNA were found some thermodynamic parameters. Using the CTDNA denaturation plots (Fig. 2) and Pace method, ${ }^{39}$ the value of $\mathrm{K}$, i.e. unfolding equilibrium constant, and $\Delta G^{\text {o }}$, i.e.

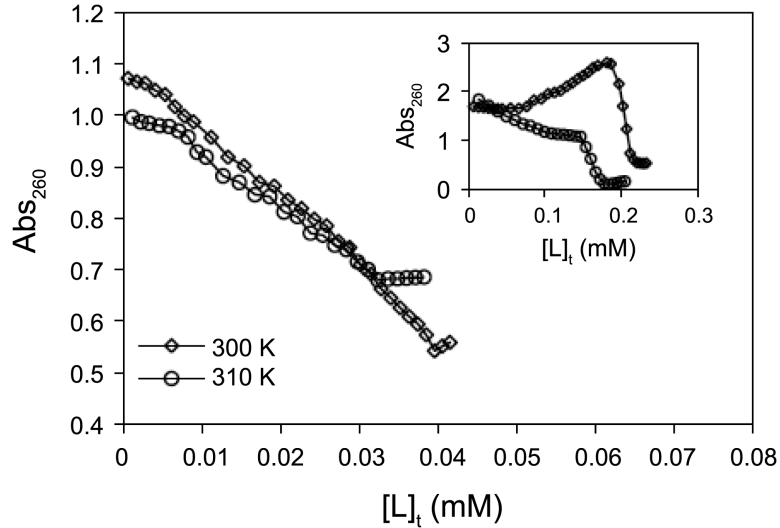

Figure 2. The changes of absorbance of CT-DNA at $\lambda_{\max }=260 \mathrm{~nm}$ due to increasing the total concentration of $[\mathrm{Pd}(\mathrm{bpy})(\mathrm{Hex}-\mathrm{dtc})] \mathrm{NO}_{3}$ and inset for $[\mathrm{Pt}(\mathrm{bpy})(\mathrm{Hex}-\mathrm{dtc})] \mathrm{NO}_{3},[\mathrm{~L}]_{\mathrm{t}}$, at constant temperatures of $300 \mathrm{~K}$ and $310 \mathrm{~K}$.

unfolding free energy of CT-DNA at two temperatures of $300 \mathrm{~K}$ and at $310 \mathrm{~K}$ in the presence of $[\mathrm{Pt} / \mathrm{Pd}(\mathrm{bpy})(\mathrm{Hex}-$ dtc) $\mathrm{NO}_{3}$ have been calculated. In this method, Pace had assumed two-state mechanism, nature and denature, and then calculated unfolding free energy of DNA i.e. $\left(\Delta \mathrm{G}^{\circ}\right)$ by using Eqs. (1) and (2):

$$
\begin{gathered}
K=\frac{A_{N}-A_{o b s}}{A_{\text {obs }}-A_{D}} \\
\Delta G^{\mathrm{o}}=-R T \operatorname{Ln} K
\end{gathered}
$$

Where $A_{o b s}$ is absorbance readings in transition region, $A_{N}$ and $A_{D}$ are absorbance readings of nature and denatured conformation of DNA, respectively. A straight line is observed when the values of $\Delta G^{0}$ are plotted against the concentrations of each metal complex in the transition region at $300 \mathrm{~K}$ and at $310 \mathrm{~K}$. These plots are shown in Figure 3 for $\mathrm{Pd}(\mathrm{II})$ and the inset for Pt(II) systems. The equation for these lines can be written as follow: ${ }^{41}$

$$
\left.\Delta G^{\mathrm{o}}=\Delta G_{\left(\mathrm{H}_{2} \mathrm{O}\right)}^{\mathrm{o}}-m \text { [complex }\right]
$$

Here the values of $\Delta G_{\left(\mathrm{H}_{2} \mathrm{O}\right)}^{\mathrm{o}}$ for each curve is measured

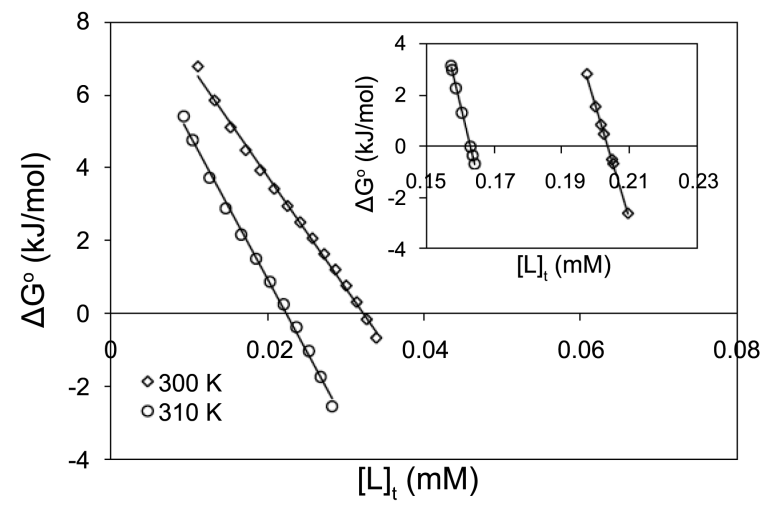

Figure 3. The molar Gibbs free energies of unfolding $\left(\Delta G^{\mathrm{o}} v s[\mathrm{~L}]_{\mathrm{t}}\right)$ of CT-DNA in the presence of $[\mathrm{Pd}(\mathrm{bpy})(\mathrm{Hex}-\mathrm{dtc})] \mathrm{NO}_{3}$ and inset for $[\mathrm{Pt}(\mathrm{bpy})(\mathrm{Hex}-\mathrm{dtc})] \mathrm{NO}_{3}$. 
Table 1. Thermodynamic parameters of CT-DNA denaturation by palladium(II) and platinum(II) complexes

\begin{tabular}{|c|c|c|c|c|c|}
\hline Compound & Temperature (K) & ${ }^{a} m(\mathrm{~kJ} / \mathrm{mol})(\mathrm{mmol} / \mathrm{L})^{-1}$ & $\begin{array}{l}{ }^{b} \Delta G_{\left(\mathrm{H}_{2} \mathrm{O}\right)}^{\mathrm{o}} \\
(\mathrm{kJ} / \mathrm{mol} \mathrm{K})\end{array}$ & $\begin{array}{c}{ }^{c} \Delta H_{\left(\mathrm{H}_{2} \mathrm{O}\right)}^{\mathrm{o}} \\
(\mathrm{kJ} / \mathrm{mol})\end{array}$ & $\begin{array}{r}{ }^{d} \Delta S_{\left(\mathrm{H}_{2} \mathrm{O}\right)}^{\mathrm{o}} \\
(\mathrm{kJ} / \mathrm{mol})\end{array}$ \\
\hline \multirow{2}{*}[\mathrm{Pd}(\mathrm{bpy})(\mathrm{Hex}-\mathrm{dtc})]{$\mathrm{NO}_{3}$} & 300 & 308.56 & 9.95 & \multirow{2}{*}{40.46} & 0.102 \\
\hline & 310 & 397.45 & 8.91 & & 0.105 \\
\hline \multirow{2}{*}{$\mathrm{Pt}(\mathrm{bpy})(\mathrm{Hex}-\mathrm{dtc}) \mathrm{NO}_{3}$} & 300 & 439.21 & 89.45 & \multirow{2}{*}{107.96} & 0.060 \\
\hline & 310 & 544.92 & 88.75 & & 0.062 \\
\hline
\end{tabular}

${ }^{a}$ Measure of the metal complex ability to destabilize CT-DNA. ${ }^{b}$ Conformational stability of CT-DNA in the absence of metal complex. ${ }^{c}$ The heat needed for CT-DNA denaturation in the absence of metal complex. ${ }^{d}$ The entropy of CT-DNA denaturation by metal complex.

from the intercept on ordinate of the plots and it is conformational stability of DNA in the absence of metal complex and the $m$ (the slope of each curve in the same plots) is a measure of the metal complex ability to destabilize CTDNA are summarized in Table 1. As we know, the higher the values of $\Delta G_{\left(\mathrm{H}_{2} \mathrm{O}\right)}^{\mathrm{r}}$, the larger the conformational stability of CT-DNA. However, the values of $\Delta G_{\left(\mathrm{H}_{2} \mathrm{O}\right)}^{\mathrm{o}}$ (Table 1) are decreased by rising the temperature. This is as expected because in general, the decrease in $\Delta G_{\left(\mathrm{H}_{2} \mathrm{O}\right)}^{\mathrm{o}}$ value is the main reason for the decrease in DNA stability. ${ }^{42}$ The values of $\mathrm{m}$ for the $\left[\mathrm{Pt}(\mathrm{bpy})(\mathrm{Hex}-\mathrm{dtc}) \mathrm{NO}_{3}\right.$ complex are much higher than those of $[\mathrm{Pd}(\mathrm{bpy})(\mathrm{Hex}-\mathrm{dtc})] \mathrm{NO}_{3}$ complex. This indicate the higher ability of $\mathrm{Pt}(\mathrm{II})$ complex to decreased the stability of CT-DNA. These $m$ values are similar to that of $\mathrm{Pd}(\mathrm{II})$ complexes as well as surfactant reported earlier. ${ }^{14}$ Another important thermodynamic parameter found is molar enthalpy of CT-DNA denaturation in absence of Pd(II) and Pt (II) complexes, $\Delta G_{\left(\mathrm{H}_{\mathrm{O}}\right)}^{\mathrm{O}}$. To find this, we calculated the molar enthalpy of CT-DNA denaturation in the presence of each metal complex, $\Delta H_{\text {conformation }}^{0}$ or $\Delta H_{\text {denaturation }}^{0}$, in the range of two temperatures using Gibbs-Helmholtz equation. ${ }^{43}$ On plotting the values of these enthalpies versus the concentration of each metal complex, straight line will be obtained which are shown in Figure 4 for Pd(II) and the inset for $\mathrm{Pt}(\mathrm{II})$ complexes. Intrapolation of these lines (intercept on ordinate, i.e., absence of metal complex) give the values of $\Delta H_{\left(\mathrm{H}_{2} \mathrm{O}\right)}^{\mathrm{O}}$ (Table 1). Moreover, the entropy of CT-DNA unfolded by $\mathrm{Pd}(\mathrm{II})$ and $\mathrm{Pt}(\mathrm{II})$ complexes, $\Delta G_{\left(\mathrm{H}_{2} \mathrm{O}\right)}^{\mathrm{O}}$ have been calculated by means of equation $\Delta G=\Delta H-\mathrm{T} \Delta \mathrm{S}$ and the data are given in Table $1 .{ }^{44}$ These data show that the metal-DNA complex is more disordered than that of native CT-DNA, because the entropy changes are positive for $\mathrm{Pd}(\mathrm{II})$ - or Pt(II)-DNA complexes in the denaturation processes of CTDNA (Table 1). The more negative values of $\Delta G_{\left(\mathrm{H}_{2} \mathrm{O}\right)}^{\mathrm{O}}$ and the large positive enthalpic and entropic values with respect

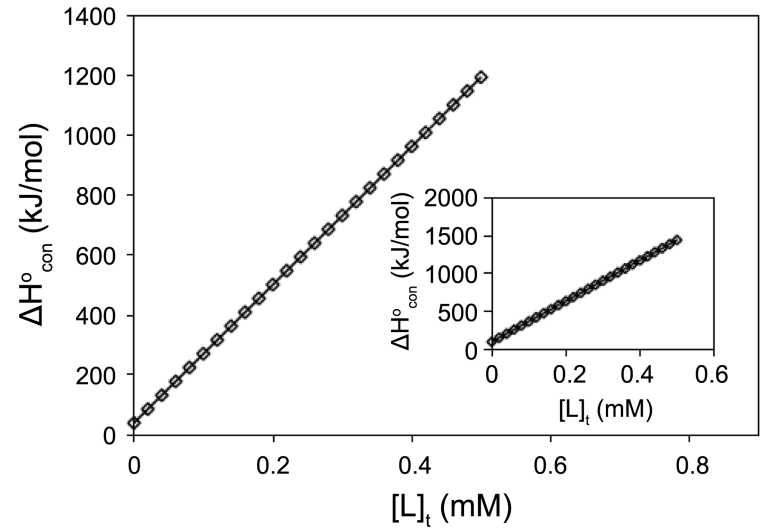

Figure 4. The molar enthalpies of DNA denaturation in the interaction with $[\mathrm{Pd}(\mathrm{bpy})(\mathrm{Hex}-\mathrm{dtc})] \mathrm{NO}_{3}$ and inset for $[\mathrm{Pt}(\mathrm{bpy})(\mathrm{Hex}-$ dtc) $\mathrm{NO}_{3}$ complexes in the range of $300 \mathrm{~K}$ to $310 \mathrm{~K}$.

to total concentration of the $\mathrm{Pd}(\mathrm{II})$ and $\mathrm{Pt}(\mathrm{II})$ complexes suggest that the interactions between the two molecules are dominated by hydrophobic rather than electrostatic forces. ${ }^{45}$ These thermodynamic parameters compare favorably well with those of Palladium (II) and platinum (II) complex as reported earlier. ${ }^{14,15,19}$

Absorption Spectral Titration Experiments. In this Part of Study Two Successive Experiments were Performed: (i) change in absorbance, A, was calculated by subtracting the absorbance reading of mixed solutions of each metal complex with various concentrations of CT-DNA, from absorbance reading of free metal complex. The values of $\Delta A_{\max }$, change in absorbance when all binding sites on CTDNA were occupied by metal complex, are given in Table 2 and Figure 5 for $\mathrm{Pd}(\mathrm{II})$ and the inset for $\mathrm{Pt}(\mathrm{II})$ systems. These values were used to calculate the concentration of metal complex bound to CT-DNA, $[\mathrm{L}]_{\mathrm{b}}$, and the concentration of free metal complex, $[\mathrm{L}]_{\mathrm{f}}$ and $v$, ratio of the

Table 2. Values of $\Delta \mathrm{A}_{\max }$ and binding parameters in the Hill equation for interaction between $\mathrm{Pd}(\mathrm{II})$ and $\mathrm{Pt}(\mathrm{II})$ complexes and CT-DNA in 20 $\mathrm{mmol} / \mathrm{L}$ Tris- $\mathrm{HCl}$ buffer and $\mathrm{pH} 7.0$

\begin{tabular}{ccccccc}
\hline Compound & Temperature $(\mathrm{K})$ & ${ }^{a} \Delta A_{\max }$ & ${ }^{b} g$ & ${ }^{c} K \times 10^{3}(\mathrm{M})^{-1}$ & ${ }^{d} n$ & ${ }^{e}$ Error \\
\hline \multirow{2}{*}{$\mathrm{Pd}(\mathrm{bpy})(\mathrm{Hex}-\mathrm{dtc}) \mathrm{NO}_{3}$} & 300 & 0.014 & 7 & 263.67 & 3.15 & 0.0518 \\
\hline \multirow{2}{*}[\mathrm{Pt}(\mathrm{bpy})(\mathrm{Hex}-\mathrm{dtc})]{$\mathrm{NO}_{3}$} & 310 & 0.011 & & 174.96 & 2.77 & 0.073 \\
& 300 & 0.08 & \multirow{2}{*}{7} & 9.98 & 3.19 & 0.0078 \\
& 310 & 0.09 & & 15.65 & 2.88 & 0.0087 \\
\hline
\end{tabular}

${ }^{a}$ Change in the absorbance when all the binding sites on CT-DNA were occupied by metal complex. ${ }^{b}$ The number of binding sites per 1000 nucleotides. ${ }^{c}$ The apparent binding constant. ${ }^{d}$ The Hill coefficient (as a criterion of cooperativity). ${ }^{e}$ Maximum error between theoretical and experimental values of $v$. 


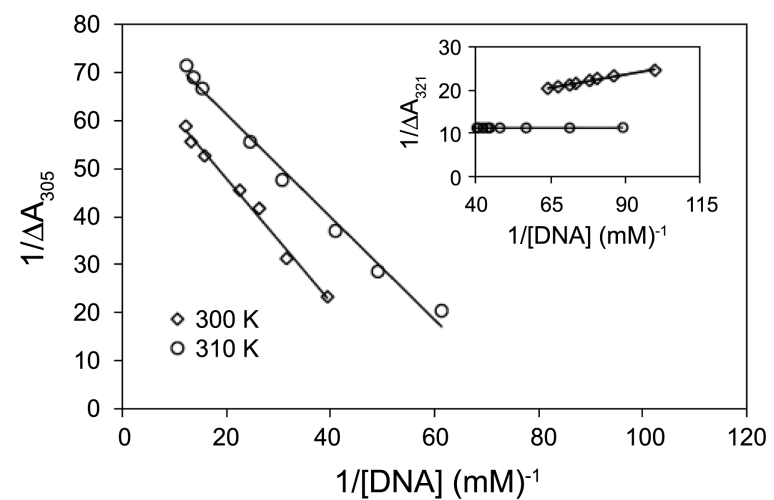

Figure 5. The changes in the absorbance of fixed amount of each metal complex in the interaction with varying amount of CT-DNA at $300 \mathrm{~K}$ and $310 \mathrm{~K}$. The linear plot of the reciprocal of DA versus the reciprocal of [DNA] for $[\mathrm{Pd}(\mathrm{bpy})(\mathrm{Hex}-\mathrm{dtc})] \mathrm{NO}_{3}$ and inset for $[\mathrm{Pt}(\mathrm{bpy})(\mathrm{Hex}-\mathrm{dtc})] \mathrm{NO}_{3}$.

concentration of bound metal complex to total [DNA] in the next experiment: (ii) a fixed amount of CT-DNA ( $25 \mu \mathrm{L}$ and $50 \mu \mathrm{L}$ from $1.1 \mathrm{mM}$ stock solution of CT-DNA for Pd(II) complex and $25 \mu \mathrm{L}$ and $24 \mu \mathrm{L}$ from $2.07 \mathrm{mM}$ stock solution of CT-DNA for Pt(II) complex at $300 \mathrm{~K}$ and $310 \mathrm{~K}$, respectively) was titrated with varying amount of each metal complex (30-80 $\mu \mathrm{L}$ and $60-150 \mu \mathrm{L}$ from $0.1 \mathrm{mM}$ stock solution of $\mathrm{Pd}(\mathrm{II})$ complex and $240-410 \mu \mathrm{L}$ and $180-270 \mu \mathrm{L}$ from $0.5 \mathrm{mM}$ stock solution of $\mathrm{Pt}(\mathrm{II})$ complex at $300 \mathrm{~K}$ and $310 \mathrm{~K}$, respectively) in total volume of $2 \mathrm{~mL}$, separately. Using these data $\left(v,[\mathrm{~L}]_{\mathrm{f}}\right)$, the Scatchard plots $^{46}$ were constructed for the interaction of each metal complexes at the two temperatures $300 \mathrm{~K}$ and $310 \mathrm{~K}$. The Scatchard plots are shown in Figure 6 for $\mathrm{Pd}(\mathrm{II})$ and the inset for Pt(II) systems. These plots are curvilinear concave downwards, suggesting cooperative binding. ${ }^{47}$ To obtain the binding parameters, the above experimental data $\left(v\right.$ and $\left.[\mathrm{L}]_{\mathrm{f}}\right)$ were substituted in equation (1), i.e., Hill equation. ${ }^{48}$

$$
\mathrm{v}=\mathrm{g}\left(\mathrm{K}[\mathrm{L}]_{\mathrm{f}}\right)^{\mathrm{n}} /\left(1+\left(\mathrm{K}[\mathrm{L}]_{\mathrm{f}}\right)^{\mathrm{n}}\right)
$$

Thus we get a series of equation with unknown parameters $n, K$ and $g$. Using Eureka software, the theoretical values of these parameters could be deduced (Table 2). The values of

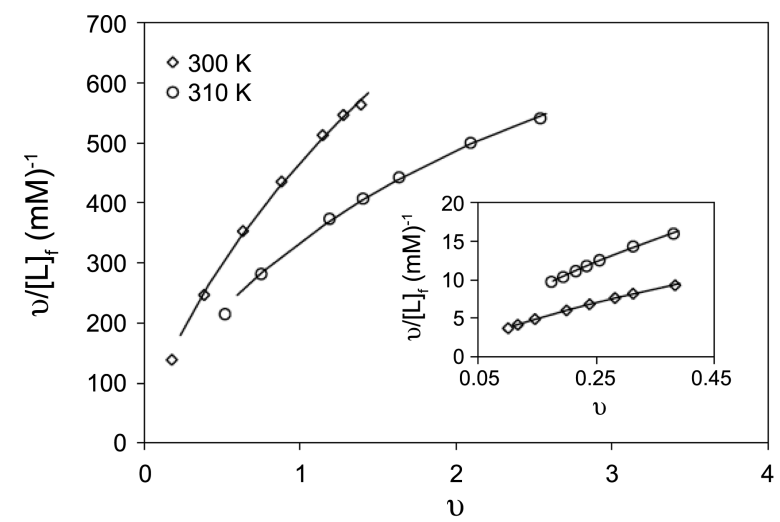

Figure 6. Scatchard plots for binding of $[\mathrm{Pd}(\mathrm{bpy})(\mathrm{Hex}-\mathrm{dtc})] \mathrm{NO}_{3}$ and inset for $[\mathrm{Pt}(\mathrm{bpy})(\mathrm{Hex}-\mathrm{dtc})] \mathrm{NO}_{3}$ to CT-DNA. $\mathrm{n}$ for two complexes will be more than 1 , which means that the systems are cooperative thus, the binding at one site increases the affinity of others. ${ }^{46}$ The apparent binding constants of two complexes obtained were $2.64 \times 10^{5} \mathrm{M}^{-1}$ at 300 $\mathrm{K}$ and $1.75 \times 10^{5} \mathrm{M}^{-1}$ at $310 \mathrm{~K}$ for $\mathrm{Pd}(\mathrm{II})$ complex and $9.98 \times 10^{3} \mathrm{M}^{-1}$ at $300 \mathrm{~K}$ and $1.56 \times 10^{4} \mathrm{M}^{-1}$ at $310 \mathrm{~K}$ for $\mathrm{Pt}(\mathrm{II})$ complex. These values are comparable to those of CTDNA intercalators $\left[\mathrm{Pd}(\mathrm{dmphen}) \mathrm{CO}_{3}\right] \cdot \mathrm{H}_{2} \mathrm{O} 1.6 \times 10^{4} \mathrm{M}^{-1},{ }^{17}$ $\left[\mathrm{Cu}(\mathrm{GFL})\left(\mathrm{A}^{1}\right) \mathrm{Cl}\right] \cdot 5 \mathrm{H}_{2} \mathrm{O} \quad 2.45 \times 10^{3} \mathrm{M}^{-1},{ }^{49}\left[(\mathrm{bpy})_{2} \mathrm{Ru}(m-\right.$ bipp)Ru(bpy $\left.)_{2}\right]\left(\mathrm{ClO}_{4}\right)_{4} 2.6 \times 10^{5} \mathrm{M}^{-1},\left[\mathrm{Ru}(\text { phen })_{2}(\mathrm{PPIP})\right]_{2}$ $1.1 \times 10^{5} \mathrm{M}^{-1}$ and $\left[\mathrm{Ru}(\mathrm{bpy})_{2}(\mathrm{PPIP})\right]_{2}{ }^{2+} 4.3 \times 10^{4} \mathrm{M}^{-150}$ and $\left[\mathrm{Ru}(\mathrm{dmb})_{2}(\mathrm{NMIP})\right]_{2} 5.46 \times 10^{3} \mathrm{M}^{-1}$. $^{51}$ Obviously, these spectral characteristics suggest that the two complexes intercalatively bind to CT-DNA, involving a strong stacking interaction between the aromatic chromophore and the base pairs of the CT-DNA..$^{52}$ Moreover, higher values of apparent binding constant of Pd(II) may be because palladium complexes are about $10^{5}$ times more labile than their platinum analogues. ${ }^{53}$ The maximum errors between experimental and theoretical values of $v$ are also shown in Table 2 that is quite low. Knowing the experimental (dots) and theoretical (lines) values of $v$ in the Scatchard plots and superimpossibility of them on each other, these values of $v$ were plotted versus the values of $\ln [\mathrm{L}]_{\mathrm{f}}$. The results are sigmoidal curves and are shown in Figure 7 for Pd(II) and the inset for Pt(II) systems at $300 \mathrm{~K}$ and $310 \mathrm{~K}$. These plots indicate positive cooperative binding at both temperatures for the two complexes. Finding the area under the above plots of binding isotherms and using Wyman-Jons equation, ${ }^{38}$ we can calculate the $\mathrm{K}_{\mathrm{app}}$ and $\Delta G_{\left(\mathrm{H}_{2} \mathrm{O}\right)}^{\mathrm{o}}$ at $300 \mathrm{~K}$ and $310 \mathrm{~K}$ for each particular $v$ and also $\Delta H_{\left(\mathrm{H}_{2} \mathrm{O}\right)}^{0^{2}}$ (Table 1). Plots of the values of $\Delta H_{\left(\mathrm{H}_{2} \mathrm{O}\right)}^{0}$ versus the values of $[\mathrm{L}]_{\mathrm{f}}$ are shown in Figure 8 for $\operatorname{Pd}(\mathrm{II})$ and the inset for $\mathrm{Pt}(\mathrm{II})$ systems at $300 \mathrm{~K}$. The changes are observed in both plots that may be due to binding of metal complexes to macromolecule or macromolecule denaturation. Similar observations can be seen in the literature where $\mathrm{Pd}(\mathrm{II})$ and $\mathrm{Pt}(\mathrm{II})$ complexes have been interacted with CT-DNA. ${ }^{15,18}$

Gel Filtration. Above results from the absorption spectroscopic studies show that the compounds in title binds to CTDNA. Binding of these complexes with CT-DNA was also studied by gel filtration using Sephadex G-25. The solution

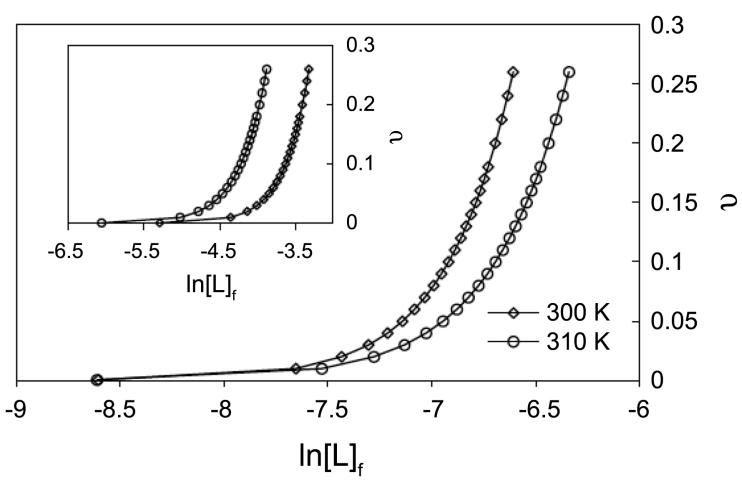

Figure 7. Binding isotherm plots for $[\mathrm{Pd}(\mathrm{bpy})(\mathrm{Hex}-\mathrm{dtc})] \mathrm{NO}_{3}$ and inset for $[\mathrm{Pt}(\mathrm{bpy})(\mathrm{Hex}-\mathrm{dtc})] \mathrm{NO}_{3}$ in the interaction with CT-DNA. 


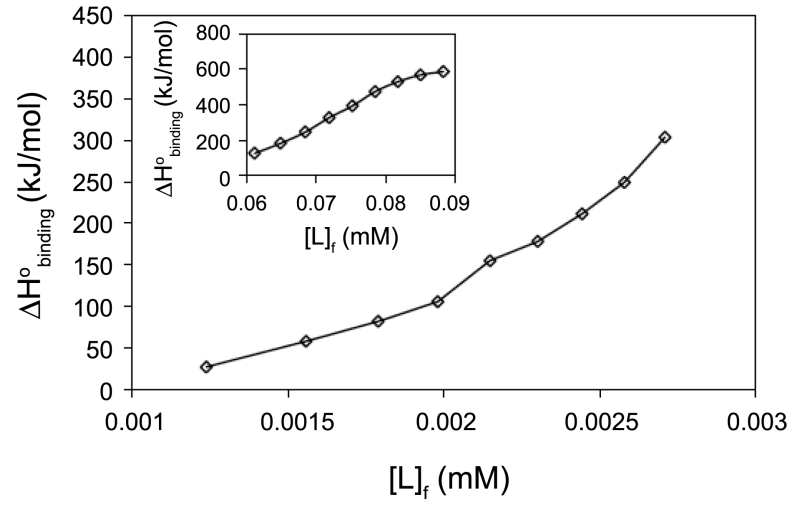

Figure 8. Molar enthalpies of binding in the interaction between CT-DNA and $[\mathrm{Pd}(\mathrm{bpy})(\mathrm{Hex}-\mathrm{dtc})] \mathrm{NO}_{3}$ and inset for $[\mathrm{Pt}(\mathrm{bpy})(\mathrm{Hex}-$ dtc) $] \mathrm{NO}_{3}$ versus free concentrations of complexes at $\mathrm{pH} 7.0$ and $300 \mathrm{~K}$.

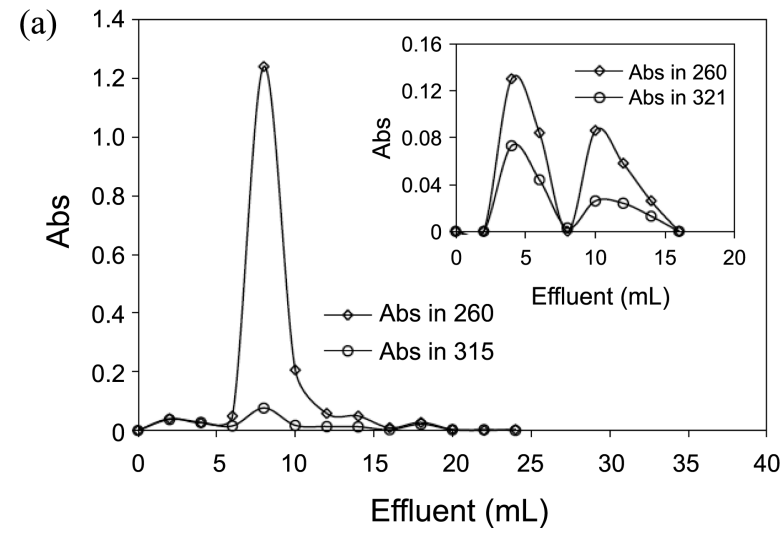

(b)

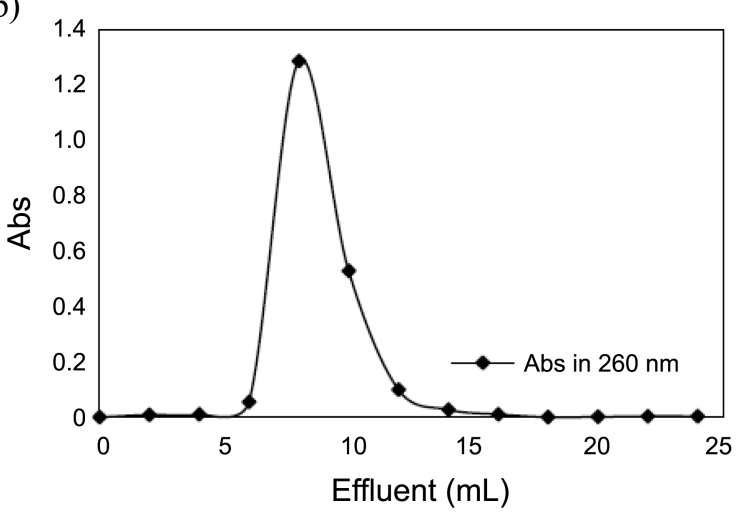

Figure 9. Gel chromatograms of $[\mathrm{Pd}(\mathrm{bpy})(\mathrm{Hex}-\mathrm{dtc})] \mathrm{NO}_{3}-\mathrm{DNA}$ complex, inset for $[\mathrm{Pt}(\mathrm{bpy})(\mathrm{Hex}-\mathrm{dtc})] \mathrm{NO}_{3}$-DNA complex (A) and free CT-DNA (B), obtained on Sephadex G-25 column.

of each interacted DNA-metal complex was passed through a Sephadex G-25 column. Elution was done with buffer and each fraction of the column was monitored spectrophotometrically at $315 \mathrm{~nm}$ and $260 \mathrm{~nm}$ for pd(II) system and at $321 \mathrm{~nm}$ and $260 \mathrm{~nm}$ for pt(II) system. The gel chromatograms obtained from plotting the values of absorbance versus the $\mathrm{mL}$ of effluents of each DNA-metal complex are shown in Figure 9 A for $\mathrm{Pd}(\mathrm{II})$ system and the inset for $\mathrm{pt}(\mathrm{II})$ system. This plot shows that the peak obtained for the two wavelengths are not resolved and suggests that the pd(II) complex has not separated from the CT-DNA. However, Pt(II) complex breaks the CT-DNA into two unequal fragments and binds to both. This clearly demonstrates that the binding between DNA and the metal complexes are not reversible under such circumstances, Because, if the interaction between DNA and metal complex was weak, the DNA should have come out of the column separately. ${ }^{14,17,54}$ To confirm the breaking of CT-DNA by Pt(II) complex, a solution of CT-DNA alone was passed through the same column and each eluted fraction of $2 \mathrm{~mL}$ was monitored at $260 \mathrm{~nm}$. The gel chromatogram obtained is shown in figure 9 B. This indicates that the CT-DNA has fragments with approximately similar molecular weights and $\mathrm{Pt}(\mathrm{II})$ complex should have been responsible to breaks it.

Fluorescence Studies. The results obtained from absorption titration and gel filtration experiments indicated that the $\mathrm{Pd}(\mathrm{II})$ and $\mathrm{Pt}(\mathrm{II})$ complexes could effectively bind to DNA. In order to confirm the binding mode and compare their binding affinities, EB displacement and Scatchard analysis experiments were carried out. ${ }^{17,55} \mathrm{~EB}$ is a conjugate planar molecule. Its fluorescence intensity is very weak, but it is greatly increased when $\mathrm{EB}$ is specifically intercalated into the base pairs of double stranded DNA. ${ }^{56}$ It has been reported that the enhanced fluorescence could be quenched, at least partially by the addition of a second molecule. ${ }^{15,57}$ which could competed with EB to bind with DNA. This is a proof that the complexes intercalate to base pairs of DNA. ${ }^{17,58,59}$

Therefore, the binding of the compounds in title were evaluated using competitive binding studies involving EB. Figure 10 showed the emission spectra of DNA-EB system with increasing amounts of the $\mathrm{Pd}(\mathrm{II})$ and $\mathrm{Pt}(\mathrm{II})$ (inset) complexes. The addition of each complex to CT-DNA pretreated with EB cause appreciable reduction in the emission intensity, indicating the replacement of EB by the complexes. 1,17

Further studies to characterize the mode of binding of $\mathrm{Pd}(\mathrm{II})$ and $\mathrm{Pt}(\mathrm{II})$ complexes to CT-DNA were carried

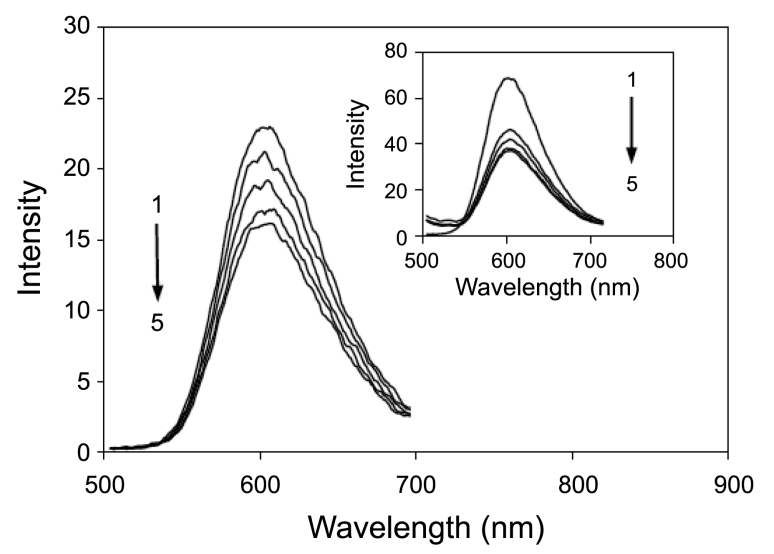

Figure 10. Fluorescence emission spectra of interacted EB-DNA in the absence (1) and presence of different concentrations of Pd(II) complex and inset for Pt(II) complex: 0.022 (2), 0.040 (3) and 0.085 (4) $\mu \mathrm{M}$ and 0.190 (2), 0.206 (3) and 0.216 (4) $\mu \mathrm{M}$, respectively, at $300 \mathrm{~K}$. 


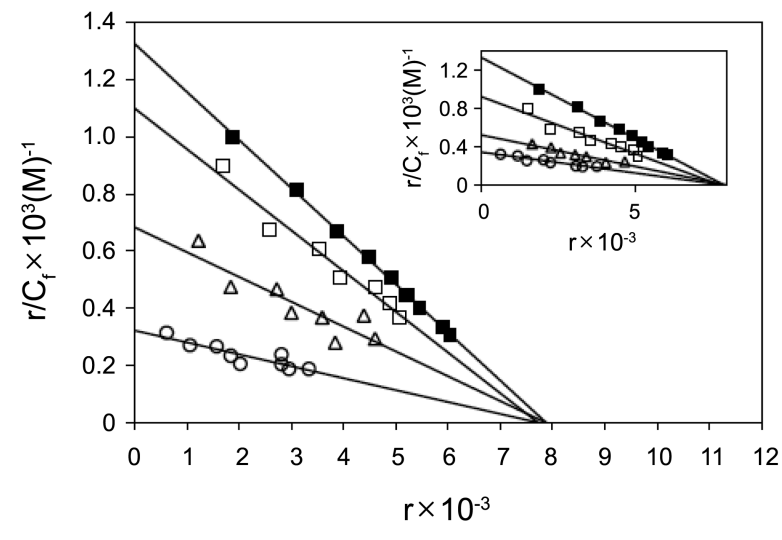

Figure 11. Competition between $[\mathrm{Pd}(\mathrm{bpy})(\mathrm{Hex}-\mathrm{dtc})] \mathrm{NO}_{3}$ and inset for $[\mathrm{Pt}(\mathrm{bpy})(\mathrm{Hex}-\mathrm{dtc})] \mathrm{NO}_{3}$ with $\mathrm{EB}$ for the binding sites of DNA (Scatchard plot). In curve no. 1, Scatchard's plot was obtained with calf thymus DNA alone. Its concentration was $60 \mu \mathrm{M}$. In curves nos. 2, 3 and 4 respectively, 22.2, 40.2 and $85.2 \mu \mathrm{M}$ for $\left[\mathrm{Pd}(\right.$ bpy)(Hex-dtc) $] \mathrm{NO}_{3}$ complex and 190.2, 205.8 and $216 \mu \mathrm{M}$ for $[\mathrm{Pt}(\mathrm{bpy})(\mathrm{Hex}-\mathrm{dtc})] \mathrm{NO}_{3}$ complex, were added, corresponding to molar ratio [complex]/[DNA] of $0.37,0.67$ and 1.42 for $[\mathrm{Pd}(\mathrm{bpy})(\mathrm{Hex}-\mathrm{dtc})] \mathrm{NO}_{3}$ complex and $3.17,3.43$ and 3.60 for [Pt(bpy)(Hex-dtc) $\mathrm{NO}_{3}$ complex. Solutions were in $20 \mathrm{mM} \mathrm{NaCl}$, $20 \mathrm{mM}$ Tris- $\mathrm{HCl}$ (pH 7.0). Experiments were done at room temperature.

out. ${ }^{18,19,57}$ The number of EB molecules intercalated to CTDNA in presence of different concentrations of the Pd(II) and Pt(II) complexes was calculated using Scatchard analysis. ${ }^{49}$ In this experiment, the wavelengths of excitation and emission were set at $540 \mathrm{~nm}$ and $700 \mathrm{~nm}$ respectively. Both have $0.5 \mathrm{~nm}$ slit widths. Solutions of CT-DNA, EB and metal complexes were prepared in Tris- $\mathrm{HCl}$ buffer of $\mathrm{pH}$ 7.0. In this medium solutions of $\mathrm{Pd}(\mathrm{II})$ and $\mathrm{Pt}(\mathrm{II})$ complexes were interacted with CT-DNA by incubating them at $300 \mathrm{~K}$ and $310 \mathrm{~K}$ for $4 \mathrm{~h}$, appropriate amount of EB was then added to them and further incubated at room temperature $(300 \mathrm{~K})$ for $2 \mathrm{~h}$ and finally processed for fluorescence spectral measurement. Saturation curves of fluorescence intensity for $[\mathrm{Pt} / \mathrm{Pd}(\mathrm{bpy})(\mathrm{Hex}-\mathrm{dtc})]^{+}$-DNA systems at different $\mathrm{r}_{\mathrm{f}}$ values (0.37, 0.67 and 1.42 for Pd(II) complex and 3.17, 3.43 and 3.60 for $\mathrm{Pt}(\mathrm{II})$ complex) were obtained in the presence of increased concentrations of EB (2, 4 to ..., $20 \mu \mathrm{M})$. The fluorescence Scatchard plots obtained for binding of EB to CT-DNA in absence ( $\square)$ and presence $(\square, \Delta, O)$ of various concentrations of $\mathrm{Pd}(\mathrm{II})$ and $\mathrm{Pt}(\mathrm{II})$ (inset) complexes are shown in Figure 11. Consequently, it might be concluded that the $\mathrm{Pd}(\mathrm{II})$ and $\mathrm{Pt}(\mathrm{II})$ complexes inhibit competitively the EB binding to DNA (type-A behavior), ${ }^{49}$ where number of intercalated molecules per 1000 nucleotide, (intercept on the abscissa) remain constant and the slope of the graphs that is $\mathrm{K}_{\text {app }}$ (apparent association constant) decrease in presence of increasing amount of complexes. The $K_{\text {app }}$ values for the $\operatorname{Pd}(\mathrm{II})$ and $\mathrm{Pt}(\mathrm{II})$ complexes are listed in Table 3. These data suggested that the interaction of the $\mathrm{Pd}(\mathrm{II})$ complex with CTDNA was stronger than that of Pt(II) complex, which were consistent with the above absorption spectral results. Compare their $\mathrm{K}_{\text {app }}$ values with those of other known DNA-
Table 3. Binding parameters for the effect of palladium and platinum complexes on the fluorescence of $\mathrm{EBr}$ in the presence of CT-DNA

\begin{tabular}{|c|c|c|c|}
\hline Compound & ${ }^{a} r_{f}$ & ${ }^{b} K \times 10^{5}(\mathrm{M})^{-1}$ & ${ }^{c} n$ \\
\hline$[\mathrm{Pd} / \mathrm{Pt}(\mathrm{bpy})(\mathrm{Hex}-\mathrm{dtc})] \mathrm{NO}_{3}$ & 0.00 & 1.68 & \multirow{7}{*}{0.0078} \\
\hline \multirow{3}{*}[\mathrm{Pd}(\mathrm{bpy})(\mathrm{Hex}-\mathrm{dtc})]{$\mathrm{NO}_{3}$} & 0.37 & 1.42 & \\
\hline & 0.67 & 0.87 & \\
\hline & 1.42 & 0.42 & \\
\hline \multirow{3}{*}[\mathrm{Pt}(\mathrm{bpy})(\mathrm{Hex}-\mathrm{dtc})]{$\mathrm{NO}_{3}$} & 3.17 & 1.19 & \\
\hline & 3.43 & 0.66 & \\
\hline & 3.60 & 0.43 & \\
\hline
\end{tabular}

intercalative complexes which possess analogical structure, $\left[\mathrm{Pd}(\mathrm{Bu}-\mathrm{dtc})\left(\right.\right.$ phen) $\mathrm{NO}_{3} 0.45 \times 10^{5} \mathrm{M}^{-1,24}$ the $\mathrm{Pd}(\mathrm{II})$ and $\mathrm{Pt}(\mathrm{II})$ complexes in our paper have similar or stronger affinities with CT-DNA.

\section{Conclusions}

2,2'-Bipyridine Pd(II) and Pt(II) complexes of hexyldithiocarbamate were prepared and characterized by analytical and spectral techniques. The absorption and fluorescence spectra studies on the interaction of the complexes with CTDNA show that the complexes have the ability of interaction with CT-DNA. Determination of several binding and thermodynamic parameters has also been attempted. These water soluble complexes cooperatively bind CT-DNA and can denature CT-DNA at very low concentration $(\sim 250 \mu \mathrm{M}$ for Pd(II) complex and $\sim 297 \mu \mathrm{M}$ for Pt(II) complex). Both complexes presumably intercalate in CT-DNA. The capability of cleavage of CT-DNA by the complexes was investigated by gel filtration, it indicates that only Pt(II) complex can break the CT-DNA into two unequal fragment and their binding with CT-DNA is strong enough not to break readily. These complexes have shown cytotoxic activity in chronic myelogenous leukemia cell line, K562, better than that of cisplatin. Thus the new synthesized palladium(II) and platinum(II) complexes may be potential anti-tumor agent due to its unique interaction mode with CT-DNA.

Acknowledgments. Support of this work by the Sistan and Baluchestan University and Tehran University are gratefully acknowledged.

\section{References}

1. Kumar, R. S.; Arunachalam, S.; Periasamy, V. S.; Preethy, Ch. P.; Riyasdeen, A.; Akbarsha, M. A. Eur. J. Med. Chem. 2008, 43, 2082.

2. Kelland, L. R. Eur. J. Can. 2005, 41, 971.

3. Pyle, A. M.; Morii, T.; Barton, J. K. J. Am. Chem. Soc. 1990, 112, 9432.

4. Qiao, Ch.; B, Sh.; Sun, Y.; Song, D.; Zhang, H.; Zhou, W. Spectrochim. Acta A 2008, 70, 136.

5. Liu, M.; Yuan, W.; Zhang, Q.; Yan, L.; Yang, R. Spectrochim. Acta A 2008, 70, 1114.

6. Kumar, C. V.; Asuncion, H. E. J. Am. Chem. Soc. 1993, 115, 22. 
7. He, X. Q.; Lin, Q. Y.; Hu, R. D.; Lu, X. H. Spectrochim. Acta A. 2007, 68, 184.

8. Kumar, R. S.; Arunachalam, S.; Periasamy, V. S.; Preethy, C. P.; Riyasdeen, A.; Akbarsha, M. A. J. Inorg. Biochem. 2009, 103, 117.

9. Shavit, M.; Peri, D.; Melman, A.; Tshuva, E. Y. J. Biol. Inorg. Chem. 2007, 12, 825.

10. Deegan, C.; McCann, M.; Devereux, M.; Coyle, B.; Egan, D. A. Cancer Lett. 2007, 247, 224.

11. Tusek-Bozic, L.; Juribasic, M.; Traldi, P.; Scarcia, V.; Furlani, A. Polyhedron 2008, 27, 1317.

12. O'Dwyer, P. J.; Stevenson, P.; Johnson, S. W. Clinical Status of Cisplatin, Carboplatin, and other Platinum-based Antitumor Drugs; Lippert, B., Ed.; Chemistry and Biochemistry of a leading Anticancer Drug; Verlag Helvetica Chimica Acta: Zurich, 1999; p 31.

13. Divsalar, A.; Saboury, A. A.; Mansouri-Torshizi, H.; Hemmatnejad, B. Bull. Korean. Chem. Soc. 2006, 27, 1801.

14. Mansouri-Torshizi, H.; I-Moghaddam, M;. Divsalar, A.; Saboury, A. A. Bioorg. Med. Chem. 2008, 16, 9616.

15. Saeidifar, M.; Mansouri-Torshizi, H.; Rezaei Behbehani, G.; Divsalar, A.; Saboury, A. A. Bull. Korean Chem. Soc. 2009, 30, 1951.

16. Chen, X.; Xie, M.; Liu, W.; Ye, Q.; Yu, Y.; Hou, Sh.; Gao, W.; Liu, Y. Inorg. Chim. Acta 2007, 360, 2851.

17. Jain, N.; Srivastava, T. S. Inorg. Chim. Acta 1987, 128, 151.

18. I-Moghaddam, M.; Mansouri-Torshizi, H.; Divsalar, A.; Saboury, A. A. J. Iran. Chem. Soc. 2009, 6, 552.

19. Mansouri-Torshizi, H.; I-Moghaddam, M.; Divsalar, A.; Saboury, A. A. J. Biomol. Struct dyn. 2009, 26, 575.

20. Palocsay, F. A.; Rund, J. V. Inorg. Chem. 1969, 8, 524.

21. Bi, Sh.; Zhang, H.; Qiao, Ch.; Sun, Y.; Liu, Ch. Spectrochim. Acta A 2008, 69, 123.

22. Li, Y.; Yang, Z.; Wang, M. Eur. J. Med. Chem. 2009, 44, 4585.

23. Reichmann, M. F.; Rice, S. A.; Thomas, C. A.; Doty, P. J. Am. Chem. Soc. 1954, 76, 3047.

24. Mansouri-Torshizi, H.; Saeidifar, M.; Divsalar, A.; Saboury, A. A.; Shahraki, S. Bull. Korean Chem. Soc. 2010, 31, 435.

25. Song, X. Q.; Wang, Y. W.; Zheng, J. R.; Liu, W. S.; Tan, M. Y. Spectrochim. Acta A 2007, 68, 701 .

26. Mital, R.; Jain, N.; Srivastava, T. S. Inorg. Chim. Acta 1989, 166, 135.

27. Gearg, W. J. J. Coord. Chem. Rev. 1971, 7, 81.

28. Gao, E.; Wang, L.; Zhu, M.; Liu, L.; Zhang, W. Eur. J. Med. Chem. 2010, 45, 311.

29. Matesanz, A. I.; Pérez, J. M.; Navarro, P.; Moreno, J. M.; Colacio, E.; Souza, P. J. Inorg. Biochem. 1999, 76, 29.

30. Gao, E.; Zhu, M.; Yin, H.; Liu, L.; Wu, Q.; Sun, Y. J. Inorg. Biochem. 2008, 102, 1958.

31. Divsalar, A.; Saboury, A. A.; Mansouri-Torshizi, H.; MoosaviMovahedi, A. A. J. Biomol. Struct. Dyn. 2007, 25, 173.

32. Mital, R.; Ray, K. S.; Srivastava, T. S.; Bahattacharya, R. K. J.
Inorg. Biochem. 1986, 27, 133.

33. Mital, R.; Srivastava, T. S. J. Inorg. Biochem. 1990, 40, 111.

34. Jiang, M.; Li, Y.; Wu, Zh.; Liu, Zh.; Yan, C. J. Inorg. Biochem. 2009, 103, 833.

35. Wolf, A.; Shimer, G. H., Jr.; Meehan, T. Biochemistry 1987, 26, 6392.

36. Liu, Z.; Wang, B.; Yang, Z.; Li, Y.; Qin, D.; Li, T. Eur. J. Med. Chem. 2009, 44, 4477.

37. Mansouri-Torshizi, H.; Islami-Moghaddam, M.; Saboury, A. A. Acta Biochim. Biophys. Sin. 2003, 35, 886.

38. Greene, R. F.; Pace, C. N. J. Biol. Chem. 1974, 249, 5388.

39. Saboury, A. A. J. Iran. Chem. Soc. 2006, 3, 1.

40. Peres-Flores, L.; Ruiz-Chica, A. J.; Delcros, J. G.; Sanches, F. M.; Ramirez, F. J. Spectrochim. Acta A 2008, 69, 1089.

41. King, A. M. Q.; Nicholson, B. H. Biochem. J. 1969, 114, 679.

42. Bathaie, S. Z.; Bolhasani, A.; Hoshyar, R.; Ranjbar, B.; Sabouni, F.; Moosavi-Movahedi, A. A. Dna Cell Biol. 2007, 26, 533.

43. Barrow, G. M. In Physical Chemistry, 5th ed.; MC. Graw-Hill: Chap. 7, New York, 1988.

44. Divsalar, A.; Saboury, A. A.; Mansouri-Torshizi, H.; Ahmad, F. J. Phys. Chem. B 2010, 114, 3639.

45. Saboury, A. A.; Shamsaei, A. A.; Moosavi-Movahedi, A. A.; Mansouri-Torshizi, H. J. Chin. Chem. Soc. 1999, 46, 917.

46. Scatchard, G. Ann. N. Y. Acad Sci. 1949, 51, 660.

47. Saboury, A. A.; Moosavi-Movahedi, A. A. Biochem. Edu. 1994, 22,48 .

48. Hill, A. V. J. Physil (Lond). 1910, 40, 4.

49. Patel, M. N.; Parmar, P. A.; Gandhi, D. S. Bioorg. Med. Chem. 2010, 18, 1227.

50. Wang, Q.; Yang, Z.; Qi, G.; Qin, D. Eur. J. Med. Chem. 2009, 44, 2425.

51. Tan, L. F.; Chao, H. Inorg. Chim. Acta 2007, 360, 2016.

52. Peng, B.; Chen, X.; Du, K.; Yu, B.; Chao, H.; Ji, L. Spectrochim. Acta A 2009, 74, 896.

53. Hacker, M. P.; Douple, E. B.; Krakoff, I. H. In Platinum Coordination Complexes in Cancer Chemotherapy; Nijhoff, M. A., Ed.; Boston, 1984.

54. Mansouri-Torshizi, H.; Saeidifar, M.; Divsalar, A.; Saboury, A. A. Spectrochim. Acta A 2010, 77, 312.

55. Wu, F.; Xiang, Y.; Wu, Y.; Xie, F. J. Luminesc. 2009, 129, 1286.

56. Sun, Y. T.; Bi, S. Y.; Song, D. Q.; Qiao, C. Y.; Mu, D.; Zhang, H. Q. Sens. Actuators B 2008, 129, 799 .

57. Lakowicz, J. R.; Weber, G.; Biochemistry 1973, 12, 4161.

58. Bai, G. Y.; Wang, K. Z.; Duan, Z. M.; Gao, L. H. J. Inorg. Biochem. 2004, 98, 1017.

59. Tysoe, S. A.; Kopelman, R.; Schelzig, D. Inorg. Chem. 1999, 38, 5196.

60. Mansuri-Torshizi, H.; Mital, R.; Srivastava, T. S.; Parekh, H.; Chitnis, M. P. J. Inorg. Biochem. 1991, 44, 239. 